Review Article

\section{Current challenges in plant breeding to achieve zero hunger and overcome biotic and abiotic stresses induced by the global climate changes: A review}

\author{
Gniech Karasawa Marines Marli* \\ State University of Sao Paulo "Julio Mesquita Filho" (UNESP), Brazil
}

\section{Abstract}

According Sustainable Development goals until 2030 we should have zero hunger and undernourished people in the world. But to achieve this goal plant breeders must improve plants in order to produce at least the double than is produced now. This is not a easy pathway because we have only few years, but considering that plant breeding programs normally take several years to produce improved genotypes, also the further improved plants should face with pest, disease and other abiotic factors that are increasing with the current climate changes. In this review we will discuss the situation of hunger in the world and the remaining available land to increase food production, point out effects of biotic and abiotic factors on the food production and present some ways that can be used to fastening plant breeding.
More Information

*Address for Correspondence: Gniech Karasawa Marines Marli, State University of Sao Paulo "Julio Mesquita Filho" (UNESP), Brazil, Email: marines.gniech@unesp.br

Submitted: July 13, 2021

Approved: July 27, 2021

Published: July 28, 2021

How to cite this article: Marines Marli GK Current challenges in plant breeding to achieve zero hunger and overcome biotic and abiotic stresses induced by the global climate changes: A review. J Plant Sci Phytopathol. 2021; 5: 053-057.

DOI: 10.29328/journal.jpsp.1001060

Copyright: ๑ 2021 Marines Marli GK. This is an open access article distributed under the Creative Commons Attribution License, which permits unrestricted use, distribution, and reproduction in any medium, provided the original work is properly cited.

Keywords: Pest; Disease; Abiotic factors Sustainable development; Molecular breeding; Biotechnology techniques

Check for updates

open AcCess

\section{Introduction}

Lately plant breeders have been warned that significant increase in agricultural production should be made to attend the increasing global demand for agricultural crops by the growing human population [1]. This will create the need to increase plant production in order to improve food security reducing the risk of hunger in the future. However, the increase of agricultural production is made even more difficult because of the reduction of available arable land and the current climate change and the environmental conditions where crops are grown. Until now, around $70 \%$ of the world land is currently used [2].

The projections of Tillman et al. [3] pointed out an increase of crop demand between 100 and $110 \%$ until 2050 considering the per capita consumption, and according to the projections of Ray, et al. [4] the annual increase in food production shows that it will be insufficient to attend the food demand in 2025 and in 2050 (Table 1). Therefore, extra available land will be necessary that yet doesn't exist, to cultivate the major crops and feed the world. All this is happening because the population in the world is increasing faster than crop production/area is achieved in the same time.

On the other hand, the last projections of the United Nations, DESA, Population Division, [5] pointed out that human growth will achieve 10 billion peoples in 2050 with continuous growth until the year 2100 when an equilibrium between birth and death is expected to happen (Figure 1). These continuous population increase makes crop genetic improvement of resilient species a priority [6].

Recent updates have shown that hunger in the world is slowly raising and that around 820 million people are nowadays feeling hunger, whereas the number of

\begin{tabular}{|c|c|c|c|c|c|c|}
\hline Crop production & Yeld in 2008 & Increase per year & Yeld in 2025 & Required extra land & Yeld in 2050 & Required extra land \\
\hline Maize & 5,2 tons/ha/year & $84 \mathrm{~kg} / \mathrm{ha} /$ year & 6,5 tons/ha/year & 15 millions ha & 8,6 tons/ha/year & 29 millions ha \\
\hline Rice & 4,4 tons/ha/year & $40 \mathrm{~kg} / \mathrm{ha} / \mathrm{year}$ & 4,9 tons/ha/year & 33 millions ha & 5,9 tons/ha/year & 67 millions ha \\
\hline Wheat & 3,1 tons/ha/year & $27 \mathrm{~kg} / \mathrm{ha} / \mathrm{year}$ & 3,4 tons/ha/year & 46 millions ha & 4,1 tons/ha/year & 95 millions ha \\
\hline Soybean & 2,4 tons/ha/year & $31 \mathrm{~kg} / \mathrm{h} /$ year & 3,0 tons/ha/year & 14 millions ha & 3,8 tons/ha/year & 28 millions ha \\
\hline
\end{tabular}




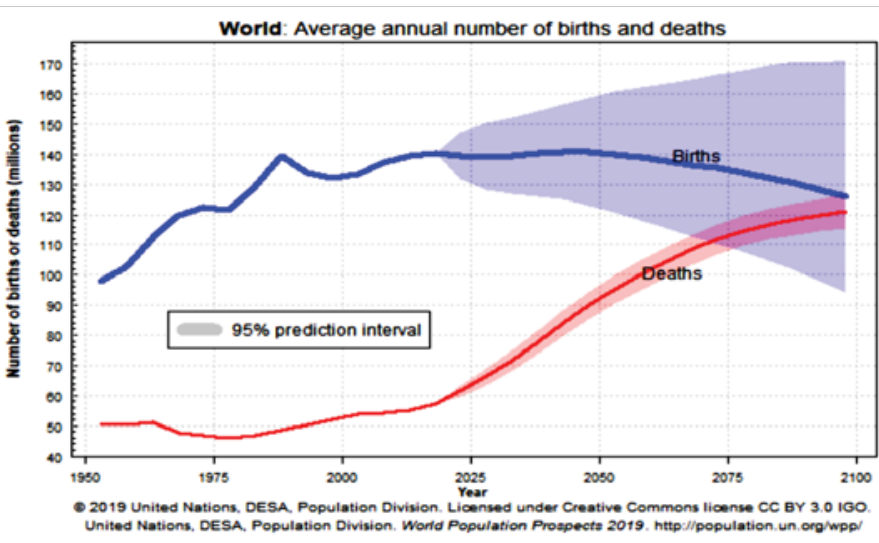

Figure 1: Projections of world population growth and death [5]

undernourished increased 10.8\% from 2018 to 2019 [2,7]. Nowadays, warnings have been published by Laborde, et al. [8] advertising that the COVID-19 pandemic status is creating an important impact on food security because the income countries have reduced access to food. In this sense, Torrero, [9], a chief economist of the Food and Agriculture Organization of United Nation (FAO), recommended that the countries around the world should join forces to avoid global food crisis because without food no health will be achieved. Last year, November $6^{\text {th }}$ the World Food Programme (WFP), together with the Food and Agriculture Organization (FAO), warned about a risk of famine in four countries, and according to FAO-WFP, [10], 20 countries were identified in the hunger hotspots.

\section{Effect of abiotic and biotic stresses on food production}

The prediction of human growth and the expected effect of global climate changes taken together with biotic and abiotic stresses will address big challenges to increase crop production, since around $70 \%$ of the total land is already used to produce food and for other purposes (Clay, 2011). Besides this, there is also the need to produce food through sustainable agricultural practices that is already endangered by several environmental factors [11] to reduce environmental impacts over soils yet highly depredated [3]. So, to avoid hunger in the future some studies have shown that global food production should double by 2050 to be able to cover the increasing projected food demand [3].

According to Rodriguez, et al. [12], extreme temperature, drought and salinity are between the major abiotic factors responsible for reducing plant productivity. It is expected that the changes in the environmental and climate conditions will promote the appearance of new pest and diseases that will reduce plant resistance [1]. Another problem recently detected by De Storme and Geellen [13] is that high temperature can induce meiotic restitution of the chromosome set during the male gamete formation. One consequence of this problem reported is be the increase of polyploid plants and, consequently, these individuals will have reduced fertility levels which represent another important challenge in the future that until now was not considered.

The loss of $33 \%$ of the total production of maize, soybean, rice and wheat in the world is explained by climate variations [14]. These values are still important to take into consideration and deal with in plant breeding because abiotic stresses like high/low temperature, drought, salinity, between others, can offer big challenges to increase crop productivity and cultivation in several locations around the world. Currently, great advance was done in the knowledge of the genetic and physiological control of the abiotic resistance, with several genes identified in annual and perennial species [15], such as genes that control saline resistance [16] and drought tolerance [17]. Also, considerable advance was made in the knowledge of the epigenetic regulation in plant abiotic stress resistance [18], like salinity and drought resistance in plants [19].

On the other hand, according to Lucas, [20], losses produced worldwide, from 2001 to 2003, by weed, pests, pathogens and viruses were around $26.3 \%$ in soybean, $28 \%$ in wheat, $28.8 \%$ in cotton, $31.2 \%$ in maize, $37.4 \%$ in rice and $40.3 \%$ in potatoes. These values are considerable if we think that around one third of the total crop production will be lost. This persistent loss of crop production by pest and diseases is one of the major barriers to achieve global food sufficiency [21]. Fortunately, substantial advance was done in the knowledge of the genetic control of the development of biotic diseases and also in the strategies that can be used for their control [1].

Despite the advances in crop species disease control, there are still several crop species affected with pest and diseases producing considerable impact and reduction on plant production [1]. To survive the species need continuously to defend them from the attack of the pathogens [22], like bacteria, virus, fungi, micoplasma, etc [23]. To defend themselves, plant species make the use of hormones that are one of the most important compounds in plant signal transduction [24]. This signaling will activate defenses at different levels in order to assure healthy plants. Fortunately, considering the high pathogen diversity available in the natural environment the rule is still "being healthy" [25] and the occurrence of disease is an exception that will occur only if two of the following factors interact: pathogen, host and environment (Figure 2). As one

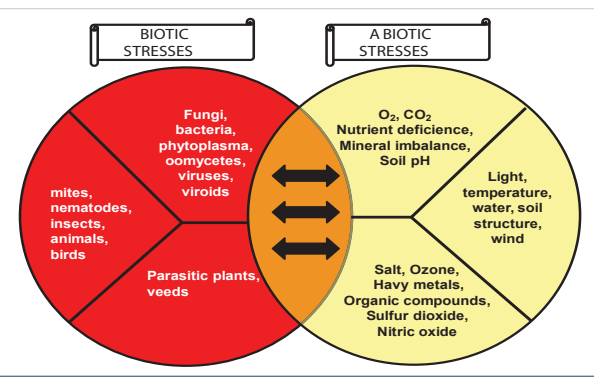

Figure 2: Biotic and abiotic factors responsible for plant disease, disorders and damage [20]. 
of these factors change, also the degree of the severity of the disease will change at individual and population levels [22]. So, for a disease to occur the pathogens need to overcome the host defense by using sabotage or by changing its appearance [25].

The knowledge about the genetic inheritance of the resistance to biotic stresses was first reported by R.H. Biffen around 116 years ago. He described for the first time the inheritance mode of resistance to the yellow wheat rust fungus observed in the F2 progeny by crossing susceptible and resistant lines [25]. After that, H.H. Flor described the segregation of flax resistance against Melampsora lini that allowed him to establish the gene-to-gene theory. Flor's studies have shown that for each resistance gene (R) in the host there was a gene present in the pathogen (Avr) [22], so it was proposed the gene-for-gene theory and summarized in the "zig-zag model" to explain the molecular activity behind the resistance behavior [26-28]. This theory improved our knowledge of the biochemical and genetic basis of the plantpathogen interaction which later allowed the identification and cloning of the $\mathrm{R}$ resistance genes [28]. The cloning and identification of these $\mathrm{R}$ genes have shown for several classes of plant pathogens that the cell death produced around the place where intracellular plant pathogens are hosted in the plant species with "hyper sensibility" resistance is produced by a receptor of molecules of the $\mathrm{R}$ plant-specific gene that is responsible for recognizing the Avr genes produced by the pathogen [22]. Therefore, we can say that the R genes are plant elicitors that recognize the pathogen genes and that pathogen genes are effectors or Pathogen Associated Molecular Patterns (PAMPS) that are responsible for the plant attack $[1,24,25]$. To overcome the host defense many pathogens use effectors that suppress the signaling pathways via sabotage and make it easy the infection process by deviating nutrients, and optimizing their living condition in the host plant [29].

Nowadays, several R genes are identified, cloned, modified and transferred to different crop species by using conventional breeding techniques, molecular Marker Assisted Selection (MAS) and/or biotechnological tools, like OMICS (genomics, transcriptomics, proteomics, metabolomics, etc.) in order to fight against pest and diseases and achieve durable resistance or tolerance by combining them with quantitative genes [28]. Thus, in smart agriculture the use of traditional crop breeding techniques is considered unsuitable to increase food production and attend the growing population by sustainable environment. Hence, tools in tissue culture techniques, like micropropagation [30], gametic embryogenesis [31,32], somatic embryogenesis, cell suspension, protoplast fusion make possible fast large scale cloning of high value plants, to produce pure lines [33], select biotic and abiotic resistant plants and improved varieties [34]. And the new tools in molecular genetics, like: OMICS [35], transgenics, gene editing $[36,37]$ and MAS make possible to put together different biotic resistance genes to obtain durable resistant lines in a short time [11]. Also, interference RNA technology can be used to activate and silence genes in order to achieve the desired phenotype [38-40].

Not all abiotic factors can be reversed by plant breeding technologies. Some abiotic factors can be reduced by applying modern cultivation technologies like environmental management practices and link microbes to plants is it possible to promote biocontrol against pathogens [41,42]. Also, the application of applying diethyl aminoethyl hexanoate, will increase plant resistance to abiotic stress, like cold $[43,44]$ and salinity resistance [45]. And, using the proline aminoacid during plant acclimatization has shown to increase tolerance to salt stress [46] and to lower water condition [47].

Between the 17 goals of the Agenda for Sustainable Development adopted by the UN States members, the aim of the goal 2 is to achieve zero hunger, finish all malnutrition and double the crop productivity until 2030 [48]. To achieve this goal in the few years that remain to increase crop productivity, plant breeders need to deal hard not only producing improved genotypes for enhancing food production, but also producing resistant genotypes for the current and foreseen biotic and abiotic factors that the current change in climate will bring.

\section{So, what can we do to achieve the goal 2 of Sustainable Development?}

One of the biggest challenges to plant breeders' scientists is to achieve novel solutions to increase food production in the current climate change [21]. So, in our opinion to reach the goal 2, plant breeders need firstly to reduce the impact of climate change on crop production by developing improved varieties genetically resilient or tolerant to biotic and abiotic factors [49], like drought and high temperature which will exert strong effect over the developmental time of plant life-cycle (Snowdon, et al. 2020) and affect greatly the plantpathogen interactions [21].

Once several $\mathrm{R}$ resistance genes to biotic and abiotic stresses are known and available on genome data banks, such as NCBI, between others, plant breeders can use these sequences to design primers and use as molecular markers to search and identify species-specific resistance genes in the germplasm banks or at germplasm collections [50,51]. Identified resistant plants can be used to produce pure lines by traditional breeding approach, with subsequent selfing along 7 generations, or to make it faster by using in vitro gamete embryogenesis. The use of gametic embryogenesis is interesting because it allows producing in only one generation completely homozygous plants, reducing time and cost in pure line production. These pure lines can be used in crossings to produce hybrids by traditional breeding, reverse breeding, gene editing and make transgenic plants. Gametic embryogenesis is also interesting to induce mutation and produce transgenic plants before doubling the chromosome 
number, so we will avoid hemizygosis, reducing time and costs with evaluation and conventional crossing to obtain homozygous plants. The time can also be reduced by using in vitro selection of resistant plants to biotic and abiotic factors, by using somatic embryogenesis and gamete fusion [34] to produce elite lines in a shorter time [52].

Genetic introgression also can be made by crossing wild relatives with elite plants and applying recurrent selection in order to increase the elite genome in resistant plants. If the resistance gene is found in the cytoplasm of the wild species it should be used as mother plant in the crossing and recurrent selection in order to conserve the resistance gene, otherwise it is independent. This process can be accelerated by using assisted selection with molecular markers. On the other hand, the resistance gene can be transferred by genetic engineering to the desired crop.

The integration of in vitro techniques, like gametic embryogenesis [31,32], plant cell and tissue culture, somatic embryogenesis, protoplast fusion [33] and mutagenesis to the modern biotechnology techniques, like: transgenic plants, synthetic biology, gene editing [6], interference RNAs [38-40] and other OMICS technologies can be used to speed the resistance in improved plants to biotic and abiotic factors and to modulate plant root depth or change plant architecture (Snowdon, et al. 2020). On the other hand, once susceptibility genes are identified, it is possible to use gene editing technologies in order to build resistant plants against different pathogens, and considering that QTLs are not racespecific and that we can combine them with $\mathrm{R}$ race-specific resistant genes to promote an effective and durable resistance in different environments [28], both strategies are highly recommended to deal with climate changes. Thus, according to Cobb, et al. [53], the public sectors should integrate new technologies to the Mendelian genetics and the principles of quantitative genetics in order to make vigorous change in crop productivity.

Another way to increase resistance is by using microbial biotechnology to enhance plant nutrition and/or promote biocontrol against pathogens [41,42], applying diethyl aminoethyl hexanoate to achieve resistance to abiotic stress [43-45], and use the prolineto increase salt tolerance [46] and low water condition [47].

\section{Acknoledgement}

The author wish thank to Elizabeth Ann Veasey for English reviewing the manuscript. The author is grateful to the anonymous reviewers for their suggestions.

\section{References}

1. Bekeko Z, Mulualem T. Genetics of plant-pathogen interactions and resistance. J Gene Environ Resour Conservat. 2016; 4: 123-134.

2. FAO. World food and agriculture statistical pocketbook 2020. Rome 2020. http://www.fao.org/documents/card/en/c/cb1521en/
3. Tilman D. Global food demand and the sustainable intensification of agriculture. Proc Nat Academy Sci. 2011; 108: 20260-20264

4. Ray DK, Mueller ND, West PC, Foley JA. Yield trends are insufficient to double global crop production by 2050. PloS One. 2013; 8: e66428. PubMed: https://pubmed.ncbi.nlm.nih.gov/23840465/

5. United Nations, DESA, Population Division. World population prospects 2019, Volume II: Demografic profiles (ST/ESA/SER.A/427). 2019.

6. Steinwand MA, Ronald PC. Crop biotechnology and the future of food. Nat Food. 2020; 1: 273-283.

7. FAO. World food and agriculture statistical pocketbook 2019. Rome. 2019. http://www.fao.org/3/ca6463en/ca6463en.pdf

8. Laborde D, Martin W, Swinnen J, Vos R. COVID-19 risks to global food security. Science. 2020; 369: 500-502. PubMed: https://pubmed.ncbi.nlm.nih.gov/32732407/

9. Torero M. Without food, there can be no exit from the pandemic Nature. 2020. https://www.nature.com/articles/d41586-020-011813 ?faodatalab $=2020-04-23$

10. FAO-WFP. Hunger hotspots: FAO-WFP early warning on acute food insecurity (March to July outlook). 2020. https://www.wfp.org/ publications/fao-wfp-early-warning-analysis-acute-food-insecurityhotspots-november-2020

11. Dormatey R, Sun C, Ali K, Coulter JA, Bi Z, et al. Gene pyramiding for sustainable Crop improvement against biotic and abiotic stresses. Agronomy. 2020; 10: 1255.

12. Rodriguez M, Canales E, Borras-Hidalgo O. Molecular aspects of abiotic stress in plants. Biotecnologia Aplicada. 2005; 2: 1-10.

13. De Storme N, Geelen D. high temperatures alter cross-over distribution and induce male meiotic restitution in Arabidopsis thaliana. Commun Biol. 2020; 3: 1-15.

PubMed: https://pubmed.ncbi.nlm.nih.gov/32327690/

14. Ray DK, Gerber JS, MacDonald GK, West PC. Climate variation explains a third of global crop yield variability. Nature Commun. 2015; 6: 5989.

15. Mousavi S, Regni L, Bocchini M, Mariotti R, Cultrera NG, et al. Physiological, epigenetic and genetic regulation in some olive cultivars under salt stress. Sci Rep. 2019; 9: 1093.

16. Zhao C, Zhang H, Song C, Zhu JK, Shabala S. Mechanisms of plant responses and adaptation to soil salinity. The innovation. 2020; 1 : 100017.

17. Faraji S, Filiz E, Kazemitabar SK, Vannozzi A, Palumbo F, et al. The AP2/ERF gene family in Triticum durum: genome-wide identification and expression analysis under drought and salinity stresses. Genes. 2020; 11: 1464

18. Chang YN, Zhu C, Jiang J, Zhang H, Zhu JK, et al. Epigenetic regulation in plant abiotic stress responses. J Integr Plant Biol. 2020; 62: 563-580. PubMed: https://pubmed.ncbi.nlm.nih.gov/31872527/

19. Banerjee A, Roychoudhury A. Epigenetic regulation during salinity and drought stress in plants: Histone modifications and DNA methylation. Plant Gene. 2017; 11: 199-204.

20. Lucas JA. Plant Pathology and Plant Pathogens. $4^{\text {th }}$ Ed. John Willey \& Sons. 2020; 432.

21. Kim JH, Hilleary R, SerokaA, HeSY.Crops of the future: building a climateresilient plant immune system. Curr Opin Plant Biol. 2021; 60: 101997. PubMed: https://pubmed.ncbi.nlm.nih.gov/33454653/

22. Agrios GN. Plant Pathology. $5^{\text {nd }}$ ed. San Diego: Elsevier. 2005

23. Hammond-Kosack KE, Jones JDG. Responses to plant-pathogens. In: Buchanan, B.B, Gruissen, W, Jones, R.L. Biochemistry and molecular biology of plants. $2^{\text {nd }}$ ed. Oxford: Willey Blackwell. Chapter 21. 2015.

24. Hulak N, González Plaza JJ. Plant-Pathogen Interactions: A Brief 
Insight into a Complicated Story. Agricul Conspectus Sci. 2015; 80 217-222.

25. Camargo LEA. Genética da interação patógeno-hospedeiro. In Amorim, L, Rezende, J.A.M, Bergamin Filho, A. Manual de fitopatologia: princípios e conceitos. $5^{\mathrm{a}}$ ed, Viçosa: Ceres, Cap. 156. 2018a.

26. Pascholati SFP, Dalio RJD. Fisiologia do parasitismo: como os patógenos atacam as plantas. In. Amorim L, Rezende JAM, Bergamin Filho, A. Manual de fitopatologia. $5^{\mathrm{a}}$ ed, Viçosa: Ceres, Cap. 34. $2018 \mathrm{~b}$.

27. Camargo LEA. Contole genético. In. Amorim L, Rezende JAM, Bergamin Filho A. Manual de fitopatologia: princípios e conceitos. $5^{\text {a }}$ ed, Viçosa: Ceres, Cap. 15. 2018.

28. Kaur B, Bhatia D, Mavi GS. Eighty years of gene-for-gene relationships and its application and utilization of R genes. J Gen. 2021; 100: 50. PubMed: https://pubmed.ncbi.nlm.nih.gov/34282731/

29. Meisrimler CN, Allan C, Eccersall S, Morris RJ. Interior design: how plant pathogens optimize their living conditions. New Phytologist. 2021; 229: 2514-2524.

30. Karasawa MMG, Pinto JEBP, Pinto JC, Pereira AV. Proliferação de capim elefante em diferentes concentrações de regulador de crescimento e consistências do meio de cultura. Ciência e Agrotecnologia. 2002; 26 : 1243-1251.

31. Karasawa MMG, Chiancone B, Gianguzzi V, Abdelgalel AM, Botta R, et al. Gametic embryogenesis through isolated microspore culture in Corylus avellana L. Plant Cell, Tissue and Organ Culture (PCTOC). 2021; 124: 635-647.

32. Chiancone B, Karasawa MMG, Gianguzzi V, Abdelgalel AM, Bárány I et al. Early embryo achievement through isolated microspore culture in Citrus clementina Hort. ex Tan, cvs. 'Monreal Rosso'and 'Nules'. Frontiers in plant science. 2015; 6: 413.

33. Gniech-Karasawa MM. Gametic embryogenesis, somatic embryogenesis, plant cell cultures, and protoplast fusion: Progress and Opportunities in Biofuel Production. Plant-Based Genetic Tools for Biofuels Production. 2017; 15.

34. Gerald NDLF, Frei UK, Lübberstedt T. Accelerating plant breeding. Trends Plant Sci. 2013; 18: 667-672.

PubMed: https://pubmed.ncbi.nlm.nih.gov/24080381/

35. Bhardwaj A, Devi P, Chaudhary S, Rani A, Jha UC, Kumar S, et al. 'Omics' approaches in developing combined drought and heat tolerance in food crops. Plant Cell Rep. 2021; 1-41.

PubMed: https://pubmed.ncbi.nlm.nih.gov/34223931/

36. Biswas S, Zhang D, Shi J. CRISPR/Cas systems: opportunities and challenges for crop breeding. Plant Cell Rep. 2021; 40: 979-998.

37. Qaim M. Role of new plant breeding technologies for food security and sustainable agricultural development. Appl Econo Perspect Policy. 2020; 42: 129-150.

38. Liu S, Geng S, Li A, Mao Y, Mao L. RNAi technology for plant protection and its application in wheat. BIOTECH. 2021; 1-10.

39. Dalakouras A, Wassenegger M, Dadami E, Ganopoulos I, Pappas ML, et al. Genetically modified organism-free RNA interference: exogenous application of RNA molecules in plants. Plant Physiol. 2020; 182: 38-50. PubMed: https://pubmed.ncbi.nlm.nih.gov/31285292/
40. Sinha SK, Patil BL. Applications of RNA-Interference and VirusInduced Gene Silencing (VIGS) for Nutritional Genomics in Crop Plants. Phytonutritional Improvement of Crops. 2017; 185.

41. Yadav AN, Kour D, Kaur T, Devi R, Guleria G, et al. Microbial biotechnology for sustainable agriculture: current research and future challenges. New and Future Developments in Microbial Biotechnology and Bioengineering. 2020; 331-344.

42. Okungbowa FI, Shittu HO, Obiazikwor HO. Endophytic Bacteria: Hidden Protective Associates of Plants against Biotic and Abiotic Stresses. Notulae Scientia Biologicae. 2019; 11: 167-174.

43. Lu J, Guan P, Gu J, Yang X, Wang F, et al. Exogenous DA-6 improves the low night temperature tolerance of tomato through regulating cytokinin. Front Plant Sci. 2021; 11: 599111. PubMed: https://pubmed.ncbi.nlm.nih.gov/33613581/

44. Zhang J, Li S, Cai Q, Wang Z, Cao J, et al. Exogenous diethyl aminoethyl hexanoate ameliorates low temperature stress by improving nitrogen metabolism in maize seedlings. PloS One. 2020; 15: e0232294. PubMed: https://pubmed.ncbi.nlm.nih.gov/32353025/

45. Zhang C, He P, Li Y, Li Y, Yao H, et al. Exogenous diethyl aminoethyl hexanoate, a plant growth regulator, highly improved the salinity tolerance of important medicinal plant Cassia obtusifolia L. J Plant Growth Regula. 2016; 35: 330-344.

46. Naliwajski M, Skłodowska M. The relationship between the antioxidant system and proline metabolism in the leaves of cucumber plants acclimated to salt stress. Cells. 2021; 10: 609.

PubMed: https://www.ncbi.nlm.nih.gov/pmc/articles/PMC7998282/

47. Ghaffari H, Tadayona MR, Bahadora M, Razmjoob J. Investigation of the proline role in controlling traits related to sugar and root yield of sugar beet under water deficit conditions. Agri Water Management. 2021; 243: 106448

48. United Nations DESA. Sustainable development goals. 2015; https://sdgs.un.org/goals

49. Kilian B, Dempewolf H, Guarino L, Werner P, Coyne C, et al. Crop Science special issue: Adapting agriculture to climate change: A walk on the wild side. Crop Sci. 2021; 61: 32-36.

50. Dwivedi SL, Scheben A, Edwards D, Spillane C, Ortiz R. Assessing and exploiting functional diversity in germplasm pools to enhance abiotic stress adaptation and yield in cereals and food legumes. Front Plant Sci. 2017; 8: 1461.

PubMed: https://pubmed.ncbi.nlm.nih.gov/28900432/

51. Jones H, Gosman N, Horsnell R, Rose GA, Everest LA, et al. Strategy for exploiting exotic germplasm using genetic, morphological, and environmental diversity: the Aegilops tauschii Coss. example. Theor Appl Gene. 2016; 126: 1793-1808.

PubMed: https://pubmed.ncbi.nlm.nih.gov/23558983/

52. Palanisamy D, Marappan S, Ponnuswamy RD, Mahalingam PS, BoharR, et al. Accelerating hybrid rice breeding through the adoption of doubled haploid technology for R-line development. Biologia. 2019; 74: 12591269.

53. Cobb JN, Juma RU, Biswas PS, Arbelaez JD, Rutkoski J, et al. Enhancing the rate of genetic gain in public-sector plant breeding programs: lessons from the breeder's equation. Theo Appl Gene. 2019; 132: 627-645. 